\title{
KONSEP MANAJEMEN KELAS
}

\author{
Hamidah D \\ Dosen STKIP Budidaya Binjai
}

\begin{abstract}
ABSTRAK
Artikel ini bertujuan untuk mendeskripsikan bagaimana pentingnya manajemen kelas dalam proses pembelajaran. Manajemen kelas dan pengajaran adalah dua kegiatan yang sangat erat hubungannya, namun dapat dan harus dibedakan satu sama lain karena tujuannya berbeda. Kalau pengajaran mencakup semua kegiatan yang secara langsung dimaksudkan untuk mencapai tujuantujuan khusus pengajaran. Manajemen kelas menunjukkan kepada kegiatan-kegiatan yang mencakup dan memperhatikan kondisi yan optimal bagi terjadinya pfroses belajar-mengajar. Dalam kegiatan belajar mengajar terdapat dua hal yang turut menentukan berhasil tidaknya suatu proses belajar mengajar, yaitu pengaturan kelas dan pengajaran itu sendiri. Kedua hal itu saling tergantung. Keberhasilan pengajaran dalam arti tercapainya tujuan-tujuan instruksional, sangat tergantung pada keterampilan manajemen kelas. Kelas yang baik dapat menciptakan situasi yang memungkinkan anak belajar sehingga merupakan titik awal keberhasilan pengajaran. Proses ini bisa berjalan berkat kerja sama antara individu dan kelompok serta sumber daya lainnya dalam mencapai tujuan pendidikan dalam hal ini sekolah. Dalam proses pembelajaran di kelas yang harus dilakukan oleh seorang guru adalah mengupayakan atau menciptakan kondisi belajar mengajar yang baik. Dengan kondisi belajar yang baik diharapkan proses belajar mengajar akan berlangsung dengan baik pula. Proses pembelajaran yang baik akan meminimalkan kemungkinan terjadinya kegagalan serta kesalahan dalam pembelajaran. Maka dari itu penting sekali bagi seorang guru memiliki kemampuan menciptakan kondisi belajar mengajar yang baik dan untuk mencapai tingkat efektivitas yang optimal dalam kegiatan instruksional kemampuan manajemen kelas merupakan salah satu faktor yang harus dikuasai oleh seorang guru
\end{abstract}

kata kunci: manajemen kelas

\section{PENDAHULUAN}

Keberhasilan guru melaksanakan kegiatan pembelajaran tidak saja menuntut kemampuan menguasai materi pelajaran, strategi dan metode pembelajaran. Tetapi guru melaksanakan tugas profesionalnya dituntut kemampuan lainnya yaitu menyediakan atau menciptkan situasi dan kondisi belajar mengajar bisa dilaksanakan dengan baik sesuai perencanaan dan mencapai tujuan sesuai yang kehendaki. Kondisi kelas yang kondusif dan menyenangkan dapat terwujud apabila guru mampu mengatur suasana pembelajaran, mengkondisikan siswa untuk belajar dan memanfaatkan atau menggunakan sarana pengajaran serta dapat mengendalikan dalam suasana yang menyenangkan untuk mencapai tujuan pelajaran.

Manajemen kelas merupakan sebuah upaya yang real untuk mewujudkan suatu kondisi proses atau kegiatan belajar mengajar yang menyenangkan. Dengan manajemen 
kelas yang baik diharapkan dapat mendukung tercapainya tujuan pembelajaran dimana proses tersebut memberikan pengaruh positif yang secara langsung menunjang terselenggaranya proses belajar mengajar. Manajemen kelas merupakan komponen penting dalam manajemen pendidikan, yang mana di dalam kelaslah aplikasi dari manajemen yang lain akan dirasakan langsung oleh peserta didik, baik itu terkait dengan sarana prasarana, kurikulum ataupun pembelajarannya.

Harus dipahami bahwa kelas merupakan media pertemuan segala komponen pendidikan. Seorang guru yang tidak mempelajari tentang menejemen kelas dalam manajemen kelasnya tidak akan dapat mencapai tujuan pendidikan secara efektif karena apa yang dilakukan untuk mencapai tujuan harus berpijak pada perilaku yang sistematis dan berhubungan dengan konsep, asumsi, dan generalisasi manajemen pendidikan dalam kelas.

Seorang guru harus mengupayakan atau menciptakan kondisi belajar mengajar yang baik. Dengan kondisi belajar yang baik diharapkan proses belajar mengajar akan berlangsung dengan baik pula. Proses pembelajaran yang baik akan meminimalkan kemungkinan terjadinya kegagalan serta kesalahan dalam pembelajaran. Maka dari itu penting sekali bagi seorang guru memiliki kemampuan menciptakan kondisi belajar mengajar yang baik melalui manajemen kelas yang baik.

\section{KAJIAN TEORI}

\section{Pengertian Manajemen Kelas}

Winataputra dkk (1999:26-27) bahwa manajemen kelas adalah serangkaian kegiatan yang dilakukan guru untuk mendorong munculnya tingkah laku siswa yang diharapkan dan menghilangkan tingkah laku yang tidak diharapkan, mengembangkan hubungan interpersonal yang baik dan iklim sosioemosional kelas yang positif, guna menciptkan organisasi kelas yang efektif. Sanjaya (2007) bahwa "manajemen kelas merupakan keterampilan guru menciptakan dan memelihara kondisi belajar yang optimal dan mengembalikannya manakala terjadi hal-hal yang dapat mengganggu suasana pembelajaran". Pendapat lain yang cukup menarik dalam buku Quantum Teaching tentang manajemen kelas, yaitu berfokus pada hubungan dinamis dalam lingkungan kelas yang mendirikan landasan dan kerangka untuk belajar. (DePorter et al, 2003). 
Sedangkan Usman (2002:97), bahwa "manajemen kelas adalah keterampilan guru untuk menciptakan dan memelihara kondisi belajar yang optimal dan mengembalikannya bila terjadi gangguan dalam proses belajar mengajar". Menurut Soetopo (2005:200), tujuan manajemen kelas pada hakikatnya telah terkandung pada tujuan pendidikan dan secara umum tujuan manajemen kelas adalah penyediaan fasilitas bagi bermacam.macam kegiatan belajar siswa sehingga subjek didik terhindar dari permasalah mengganggu seperti siswa mengantuk, enggan mengerjakan tugas, terlambat masuk kelas, mengajukan pertanyaan aneh dan lain sebagainya.

Berdasarkan uraian di atas, dapat disimpulkan bahwa manajemen kelas adalah suatu usaha yang dilakukan guru untuk menyiapkan kondisi yang kondusif agar kegiatan belajar mengajar dapat berlangsung secara lancar. Manajemen kelas sangat penting dikuasai seorang guru dan berupaya menggunakannya untuk menciptakan dan mempertahankan kondisi kelas yang menyenangkan agar anak didik dapat belajar dengan aman dan tentram sehingga tujuan pembelajaran dapat tercapai.

Pandangan mengenai manajemen kelas sebagaimana telah dikemukakan di atas intinya memiliki karakteristik yang sama, yaitu bahwa manajemen kelas merupakan sebuah upaya yang real untuk mewujudkan suatu kondisi proses atau kegiatan belajar mengajar yang menyenangkan. Dengan manajemen kelas yang baik diharapkan dapat mendukung tercapainya tujuan pembelajaran di mana proses tersebut memberikan pengaruh positif yang secara langsung menunjang terselenggaranya proses belajar mengajar. Dengan melihat konteks tersebut manajemen kelas dapat dipandang sebagai suatu usaha yang sangat penting dan harus mendapat prioritas oleh seorang guru dalam berbagai macam aktivitas yang berkaitan dengan kurikulum dan perkembangan siswa. Upaya yang dilakukan adalah dengan menciptakan kondisi belajar yang kondusif kepada siswa untuk melaksanakan kegiatan yang kreatif dan terarah.

\section{Prinsip-Prinsip Manajemen Kelas}

Menurut Djamarah dan Zain (2006:185) masalah Manajemen kelas bukanlah merupakan tugas yang ringan. Berbagai faktorlah yang menyebabkan kerumitan. Secara umum faktor-faktor dalam pengelolaan kelas dibagi menjadi dua golongan yakni faktor interen dan faktor ekstern. Dalam rangka memperkecil masalah gangguan dalam 
manajemn kelas, memperhatikan prinsip-prinsip manajemen kelas yang perlu diperhatikan oleh guru dapat diuraikan sebagai berikut:

1. Hangat dan Antusias, diperlukan dalam proses belajar mengajar. Guru yang hangat dan akrab dengan siswa selalu menunjukan antusias pada tugasnya pada aktivitasnya dapat berhasil dalam mengimplementasi pengelolaan kelas.

2. Tantangan, penggunaan kata-kata, tindakan, cara kerja dapat meningkatkan gairah siswa untuk belajar sehingga mengurangi kemungkinan munculnya tingkah laku yang menyimpang dapat menarik perhatian siswa, dan dapat mengendalikan gairah belajar siswa.

3. Bervariasi, Penggunaan alat media, gaya mengajar guru, pola interaksi antara guru dan siswa dapat mengurangi munculnya gangguan, meningkatkan perhatian siswa. Apabila penggunaanya bervariasi merupakan kunci tercapainya pengelolaan kelas yang efektif dan menghindari kejenuhan.

4. Keluwesan, tingkah laku guru untuk mengubah strategi mengajarnya dapat mencegah kemungkinan munculnya ganguan siswa serta menciptakan iklim belajar mengajar yang efektif. Keluwesan pengajaran dapat mencegah munculnya gangguan seperti keributan siswa, tidak ada perhatian, tidak mengerjakan tugas.

5. Penekanan pada Hal-hal yang positif, pada dasarnya dalam mengajar dan mendidik, guru harus menekankan pada hal-hal yang positif dan menghindari pemusatan perhatian siswa pada hal-hal yang negatif.

6. Penanaman Displin Diri, tujuan akhir pengelolaan kelas adalah siswa dapat mengembangkan disiplin diri sendiri, guru sebaiknya selalu mendorong siswa untuk melaksanakan disiplin dan guru hendaknya menjadi teladan mengenai pengendalian diri dan pelaksanaan tanggung jawab.

\section{Ruang Lingkup Manajemen Kelas}

Ruang lingkup manajemen kelas dapat diklasifikasikan menjadi dua, yaitu: (Yamin, 2009)

1. Manajemen kelas yang memfokuskan pada hal-hal yang bersifat fisik,dan

2. Manajemen kelas yang memfokuskan pada hal-hal yang bersifat non fisik.

Kedua hal tersebut perlu dikelola secara baik dalam rangka menghasilkan suasana yang kondusif bagi terciptanya pembelajaran yang baik pula. Hal-hal fisik yang perlu 
diperhatikan dalam manajemen kelas mencakup; (1) pengaturan ruang belajar dan perabot kelas, dan (2) pengaturan peserta didik dalam belajar. Pengaturan ruang belajar dan perabot kelas (meja, kursi, lemari, papan tulis, dan meja guru) hendaknya memperhatikan bentuk dan ruangan kelas, bentuk dan ukuran meja dan kursi peserta didik, jumlah dan tingktan tiap kelompok. Kemudian hal-hal yang diperhatikan guru dalam mengatur peserta didik dalam belajar mencakup siapa yang menyusun anggota kelompok, kriteria pengelompokkan (homogen, heterogen, berdasarkan minat, atau kemampuan), dan dinamika kelompok (tetap atau berubah sesuai kebutuhan). (Yamin, 2009)

Hal-hal bersifat non fisik dalam manajemen kelas memfouskan pada aspek interaksi peserta didik dengan peserta didik lainnya, peserta didik dengan guru dan lingkungan kelas maupun kondisi kelas menjelang, selama dan akhir pembelajaran. Atas dasar ini, hal yang perlu diperhatikan dalam manajemen kelas adalah aspek psikologis, sosial dan hubungan interpersonal menjadi dominan. Kegiatan manajemen kelas menunjuk pada kegiatan-kegiatan yang ditujukan untuk menciptakan dan mempertahankan kondisi yang optimal bagi terjadinya proses belajar. Masalah pengolaan kelas yang menunjuk pada aspek fisik biasanya cendrung tidak menjadi sesuatu yang berkepanjangan, tetapi pada aspek nonfisik sering kali menjadi masalah manajemen kelas yang bersifat nonfisik menjadi focus dalam pembahasan berikutnya. (Yamin, 2009)

\section{PEMBAHASAN}

\section{Konsep Manajemen Kelas}

Peningkatan mutu pendidikan sekolah perlu di dukung kemampuan mengelola dan melaksanakan manajemen kelas. Sekolah ataupun kelas perlu berkembang maju daritahun ke tahun. Karena itu, hubungan baik guru dengan murid perlu diciptakan agar terjalin iklim dan suasana pembelajaran yang kondusif dan menyenangkan. Demikian halnya penataan penampilan fisik dan kelas perlu dibina agar kelas menjadi lingkungan pendidikan yang dapat menumbuhkan kreativitas, disiplin, dan semangat belajar peserta didik. Dalam kerangka inilah dirasakan perlunya implementasi manajemen kelas.

Untuk mengimplementasikan manajemen kelas secara efektif dan efisien, guru perlu memiliki pengetahuan mengelola pembelajaran dalam kelas, perencanaan, dan pandangan yang luas tentang kelas. Disamping itu wibawa guru harus ditumbuhkemba 
ngkan dengan meningkatkan sikap kepedulian, semangat mengajar, disiplin mengajar, keteladanan dan hubungan manusiawi sebagai moral perwujudan iklim kerja yang konduksif. Dalam rangka mengimplementasikanmanajemen kelas secara efektif dan efisien, guru harus berkreasi dalam meningkatkan manajemen kelas. Guru adalah teladan dan panutan langsung para peserta didik dikelas. Oleh karena itu, guru perlu siap dengan segala kewajiban, baik manajemen maupun persiapan isi materi pengajaran. Guru juaga harus mengorganisasikan kelasnya dengan baik. Jadwal pelajaran, pembagian peserta didik, kebersihan, keindahan dan ketertiban kelas, pengaturan tempat duduk peserta didik, penempatan alat-alat dan lain-lain harus dilakukan dengan sebaik-baiknya. Suasana kelas yang menyenangkan dan penuh disiplin sangat diperlukan untuk mendorong semangat belajar peserta didik.kreativitas dan daya cipta guru untuk mengemplementasikan manajemen kelas perlu terus menerus di dorong dan dikembangkan (Mulyasa, 2002)

Prosedur manajemen kelas merupakan pedoman untuk membuat terciptanya kondisi yang optimal serta mempertahankan kondisi optimal tersebut agar proes belajar mengajar tersebut dapat berlngsung secara efektif. Prosedur yang dimaksudkan mengacu pada dua tindakan. Pertama, prosedur pengolaan kelas preventif. Prosedur ini menunjuk pada tidakan pengajar dalam mengatur peserta didik dan peralatan atau format belajar mengajar yang tepat, sehingga menumbuhkan kondisi yang menguntungkan bagi berlangsungnya proses belajar mengajar yang efektif. Kedua, prosedur manajemen kelas yang kuratif. Prosedur ini menunjuk pada langkah-langkah yang harus diambil pengajar dalam rangka mengatur peserta didik dan peralatan atau format belajar mengajar yang tepat setelah adanya masalah, hambatan, gangguan yng timbul dalam proses belajar mengajar di kelas. Harapannya akan tercipta kembali kondisi yang optimal sebagai prasyarat untuk mendukung berlangsungnya proses belajar mengajar yang baik.

Prosedur manajemen kelas yang preventif mencakup; peningkatan kesadaran diri sebagai pengajar, peningkatan kesadaran peserta didik, bersikap polos dan tulus, mengenal dan menemukan alternatif pengetahuan manajemen kelas, membuat kontrak sosial. Prosedur pengolaan kelas yang kuratif, mencakup; mengidentifikasi masalah, menganalisis maslah, menilai alternatif pemecahan masalah, dan melaksanakan satu alternatif pemecahan, monitoring dan feedback hasil pelaksanaan alternative pemecahan masalah yang dimaksud. Para guru dapat menempuh atau mengambil salah satu prosedur sesuai 
dengan kritik berangkatnya dalam manajemen kelas. Apabila mengiginkan terciptanya kondisi belajar mengajar yang menguntungkan dan belum ditemukan ada masalahmasalah, guru dapat menempuh prosedur pengelolan kelas preventif, sedangkan apabila sudah dihadapkan pada maslah-maslah dan telah timbul seperti adanya perilaku peserta didik yang menyimpang, maka prosedur kuratiflah yang harus diambil.

Dapat dikemukakan bahwa kemampuan guru mendeteksi manajemen kelas secara akurat sangat menguntungkan bagi keberhasilannya menciptakan dan memelihara kondisi optimal bagi terselenggaranya proses belajar mengajar secara efektif dan efisien.

Menurut Tim Pakar Manajemen Pendidikan UNM (2003) menjelaskan bahwa ada lima pandangan mengenai manajemen kelas, yaitu:

1. Pandangan otoriter menyatakan bahwa manajemen kelas adalah proses mengontrol tingkah laku peserta didik, dan bersifat otoritatif dan merupakan seperangkat aktivitas guru untuk menciptakan dan mempertahankan ketertiban suasana kelas;

2. Pandangan permisif yang memberikan kebebasan kepada peserta didik untuk berbuat apa saja yang diinginkannya dan merupakan seperangkat aktivitas guru untuk mengoptimalkan kebebasan peserta didik;

3. Pandangan tingkah laku yang didasarkan pada prinsip-prinsip pengubahan tingkah laku menyatakan bahwa manajemen kelas merupakan pengubahan tingkah laku peserta didik yang dikehendaki oleh tujuan belajar berdasarkan penerapan-prinsip-prinsip yang diambil dari teori penguatan, sehingga manajemen kelas didefenisikan sebagai seperangkat aktivitas pengajar untuk mengembangkan perilaku peserta didik yang tidak diinginkan, dan mengurangi atau meniadakan prilaku peserta didik yang tidak diinginkan;

4. Pandangan hubungan interpersonal yang menyatakan bahwa pengolaan kelas merupakan proses penciptaan iklim sosioemosional yang positif didalam kelas; dan

5. Pandangan sistem sosial/kelompok menyatakan bahwa kelas merupakan sistem sosial/kelompok menyatakan bahwa kelas merupakan sistem sosial dengan proses kelompok (group Process) sebagai intinya. Atas dasar ini pengolaan kelas diberi pengertian sebagai seperangkat kegiatan pengajaran untuk menumbuhkan dan mempertahankan organisasi kelas yang efektif. 


\section{SIMPULAN}

Secara umum tujuan manajemen kelas adalah penyediaan fasilitas bagi bermacammacam kegiatan belajar siswa dalam lingkungan sosial, emosional dan intelektual dalam kelas. Fasilitas yang disediakan itu memungkinkan siswa belajar dan bekerja, terciptanya suasana disiplin, perkembangan intelektual, emosional dan sikap serta aspirasi pada siswa.

Manajemen kelas adalah suatu usaha yang dilakukan guru untuk menyiapkan kondisi yang kondusif agar kegiatan belajar mengajar dapat berlangsung secara lancar. Manajemen kelas sangat penting dikuasai seorang guru dan berupaya menggunakannya untuk menciptakan dan mempertahankan kondisi kelas yang menyenangkan agar anak didik dapat belajar dengan aman dan tentram sehingga tujuan pembelajaran dapat tercapai. Kemampuan guru dalam mendeteksi manajemen kelas secara akurat sangat menguntungkan bagi keberhasilannya menciptakan dan memelihara kondisi optimal bagi terselenggaranya proses belajar mengajar secare efektif dan efisien bagi peserta didik dan akan meningkatkan minat dan semangat peserta didik dalam proses pembelajaran.

\section{REFERENSI}

DePorter, B., et al. (2003). Quantum Teaching: Mempraktikkan Quantum Learning di Luar Kelas. Terjemahan oleh Ary Nilandari, Bandung: Kaifa

Djamarah, S. B dan Zain, A. (2006). Strategi Belajar Mengajar. Jakarta: Rineka Cipta.

Mulyasa. (2002). Manajemen Berbasis Sekolah Konsep, Strategi, Dan Implementasi. Bandung : PT. Remaja Rosdakarya.

Sanjaya, W. (2007). Strategi Pembelajaran: Berorientasi Standar Proses Pendidikan. Jakarta: Kencana Prenada Media Group

Soetopo, H. (2005). Pendidikan dan Pembelajaran, Teori, Permasalahan, dan Praktek. Malang: UMM Press.

Tim Pakar Manajemen Pendidikan UNM. (2003). Manajemen Pendidikan. Surabaya: UNM

Usman, U.M. (2002). Menjadi Guru Profesional. Bandung: PT. Remaja Karya Rosda.

Winataputra, U.S., dkk. (1999). Strategi Belajar Mengajar. Jakarta: Universitas Terbuka 
Yamin, M. (2009). Manajemen Pembelajaran Kelas: Strategi Meningkatkan Mutu Pembelajaran. Jakarta: GP Press 